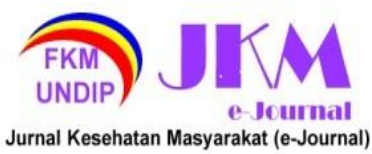

JURNAL KESEHATAN MASYARAKAT (e-Journal)

Volume 9, Nomor 6, November 2021

ISSN: 2715-5617 / e-ISSN: 2356-3346

http://ejournal3.undip.ac.id/index.php/jkm

\title{
HUBUNGAN POSTUR KERJA DAN DURASI KERJA DENGAN KELUHAN NYERI OTOT PADA PEKERJA PABRIK TAHU X DI KOTA SEMARANG
}

\author{
Rebecca Olivya Putri ${ }^{1 *}$, Siswi Jayanti ${ }^{2}$, Bina Kurniawan ${ }^{2}$ \\ ${ }^{1}$ Peminatan Keselamatan dan Kesehatan Kerja, Fakultas Kesehatan Masyarakat, Universitas \\ Diponegoro, Jl. Prof. H. Soedarto, S.H.,Tembalang, Semarang, Indonesia \\ ${ }^{2}$ Bagian Keselamatan dan Kesehatan Kerja, Fakultas Kesehatan Masyarakat, Universitas \\ Diponegoro, \\ JI. Prof. H. Soedarto, S.H.,Tembalang, Semarang, Indonesia \\ ${ }^{*}$ Corresponding author: rebeccaolivyaputri@gmail.com
}

\section{ABSTRACT}

Complaints of muscle pain are pain, heaviness, stiffness in the muscles and it can be experienced in the neck, shoulders, back, waist and other parts of the body. Generally, people who feel complaints of muscle pain originate from habits they do during work. Complaints of muscle pain can arise as a result of inappropriate work posture and a long duration of working. This study aims to analyze the correlation between work posture and work duration with complaints of muscle pain at tofu $X$ factory workers in Semarang City. This type of research is quantitative with a cross-sectional study. The sample of this research is the entire population, namely 24 workers. The research instrument is REBA (Rapid Entire Body Assessment) sheet for measuring work posture variables, the questionnaire sheet for work duration variables, NBM (Nordic Body Map) sheet for muscle pain complaint variables. The data analysis used was the Fisher Exact Test. The analysis showed a significant correlation between both work posture $(p$-value $=0.040)$ and work duration $(p$-value $=0.028)$ with complaints of muscle pain. The present study suggested further intervention that requires both engineering and administrative control measures to reduce the high percentage of muscle pain complaints among those workers.

Keywords: Work Posture, Work Duration, Complaints of Muscle Pain, Tofu Factory

\section{PENDAHULUAN}

Sektor informal merupakan salah satu sektor yang tersebar di seluruh Indonesia. Dalam suatu proses produksi sektor informal, tenaga manusia merupakan faktor yang sangat penting mengingat hingga saat ini masih banyak proses produksi yang menggunakan alat kerja manual dan melibatkan tenaga manusia sehingga dapat menyebabkan timbulnya berbagai keluhan pada tubuh pekerja salah satunya keluhan nyeri otot. ${ }^{1}$ Berdasarkan data Kementerian Kesehatan Republik Indonesia pada tahun 2013, menunjukkan bahwa penyakit musculoskeletal atau nyeri otot paling banyak dialami oleh pekerja sektor informal seperti buruh, nelayan dan petani yaitu sebanyak $31,2 \%$. Bagian-bagian tubuh yang sering mengalami keluhan musculoskeletal atau nyeri otot adalah punggung sebanyak $100 \%$, pinggang sebanyak $95,2 \%$ dan bokong sebanyak $47,6 \%$. Selain itu, data tersebut juga menunjukkan bahwa dari 15 orang responden yang diteliti terdapat 8 orang mengalami nyeri pundak, 4 orang mengalami nyeri leher hingga pundak, 2 orang mengalami nyeri bahu serta 1 orang mengalami nyeri bahu hingga punggung. $^{2}$

Keluhan nyeri otot merupakan gejala pada tubuh yang sering diderita manusia yang ditandai dengan munculnya nyeri atau sakit, berat, kaku pada otot. ${ }^{3,}{ }^{4}$ Salah satu pemicu munculnya keluhan nyeri otot pada pekerja adalah proses Manual Material Handling $(M M H)$ yaitu proses pemindahan barang secara manual. Jika pekerjaan ini dilakukan dalam jangka waktu lama dan disertai penggunaan postur tubuh yang tidak sesuai, maka dapat menimbulkan resiko gangguan pada otot. Berdasarkan penelitian mengenai analisis manual material handling pada pekerja borongan di salah satu sektor informal, pekerja merasakan nyeri otot pada bagian leher, bahu, punggung, pinggang dan bokong, hal tersebut dapat menjadi faktor penghambat kemaksimalan produktivitas kerja. ${ }^{5}$

Salah satu sektor informal yaitu Pabrik Tahu $X$ di Kota Semarang merupakan industri pembuatan tahu yang dalam proses pembuatannya berasal dari kacang kedelai. Berdasarkan wawancara dengan pemilik pabrik, pabrik tahu $X$ memiliki sejumlah 24 orang pekerja dengan rentang usia yaitu 19 tahun sampai dengan 54 tahun. Pabrik ini memiliki 1 shift kerja yaitu dari pukul 07.00 15.00 WIB dalam sehari serta beroperasi setiap hari Senin sampai hari Minggu, tetapi durasi 


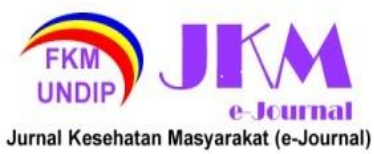

jam kerja dapat berubah atau bertambah sesuai dengan permintaan konsumen yang membuat para pekerja bekerja lebih lama dari waktu yang telah ditentukan. Namun walau demikian, pekerja memiliki jatah libur 1 hari dalam seminggu. Adapun alur produksi pabrik tahu $\mathrm{X}$ yaitu penanganan kedelai (pemilihan kedelai, pembersihan kedelai, perendaman kedelai), penggilingan kedelai (menakar kedelai, memasukan kedelai yang ditakar ke dalam mesin penggiling), pemasakan/pembuatan, penyaringan bubur kedelai, pencetakan, pemotongan, penggorengan tahu, penguapan dan pengiriman. Proses produksi pada pabrik tahu ini masih menggunakan alat-alat manual yang membutuhkan tenaga fisik manusia seperti pada proses penanganan kedelai dimana pekerja melakukan pemilihan, pembersihan dan perendaman kedelai menggunakan air dan keranjang sebagai wadah, lalu pada proses penggilingan kedelai dimana pekerja menakar, mengangkat keranjang dan memasukkan kedelai ke dalam mesin penggiling, selanjutnya pada proses pembuatan/ pemasakan dan penyaringan bubur kedelai dimana pekerja mengaduk lalu memeras bubur kedelai secara manual menggunakan kain yang diperas dan digoyang- goyangkan, lalu pada proses pencetakan, pembalikan dan pengepressan dimana pekerja mengangkat, membalik dan mencetak tahu menggunakan papan pencetak tahu dengan berat kurang lebih 2-5 kilogram, selanjutnya pada proses pemotongan tahu dimana pekerja memotong tahu menggunakan pisau atau alat pemotong manual dan seluruh proses kerja tersebut termasuk dalam proses manual material handling. Berdasarkan hasil survey yang dilakukan pada 5 orang pekerja, dapat diketahui bahwa pekerja mengalami keluhan nyeri otot pada bagian leher, bahu, lengan, punggung, pinggang, lutut dan betis yang diakibatkan oleh postur kerja yang tidak sesuai dan durasi kerja yang melebihi waktu yang telah ditentukan. Berdasarkan latar belakang di atas, maka peneliti bermaksud untuk melakukan penelitian mengenai Hubungan Postur Kerja Dan Durasi Kerja Dengan Keluhan Nyeri Otot Pada Pekerja Pabrik Tahu X Di Kota Semarang.

\section{METODE PENELITIAN}

Penelitian ini bersifat observasional deskriptif dengan pendekatan cross sectional. Penentuan sampel menggunakan teknik total sampling dan untuk analisis data menggunakan uji Fisher Exact Test. Penelitian dilakukan di Pabrik Tahu X Kota Semarang pada Maret 2021. Populasi penelitian adalah seluruh pekerja pabrik tahu $\mathrm{X}$ yang berjumlah 24 orang. Variabel yang diteliti adalah postur kerja, durasi kerja dan keluhan nyeri otot. Pengumpulan data primer dilakukan secara langsung dan tetap menerapkan protokol kesehatan dengan cara wawancara dan observasi menggunakan instrument penelitian berupa kuesioner penelitian untuk mengetahui data diri dan informasi penunjang dari responden seperti durasi kerja, masa kerja dan sikap kerja yang dilakukan. Lembar REBA (Rapid Entire Body Assessment) untuk mengidentifikasi dan menilai sikap tubuh responden pada pengukuran variabel postur kerja dan lembar NBM (Nordic Body Map) untuk mengetahui adanya keluhan dan titik nyeri otot pada variabel keluhan nyeri otot

\section{HASIL DAN PEMBAHASAN}

\section{Hasil Univariat}

Tabel 1. Distribusi Frekuensi Usia, Jenis Kelamin, Masa Kerja, Postur Kerja, Durasi Kerja dan Keluhan Nyeri Otot Pekerja Pabrik Tahu X di Kota Semarang 2021

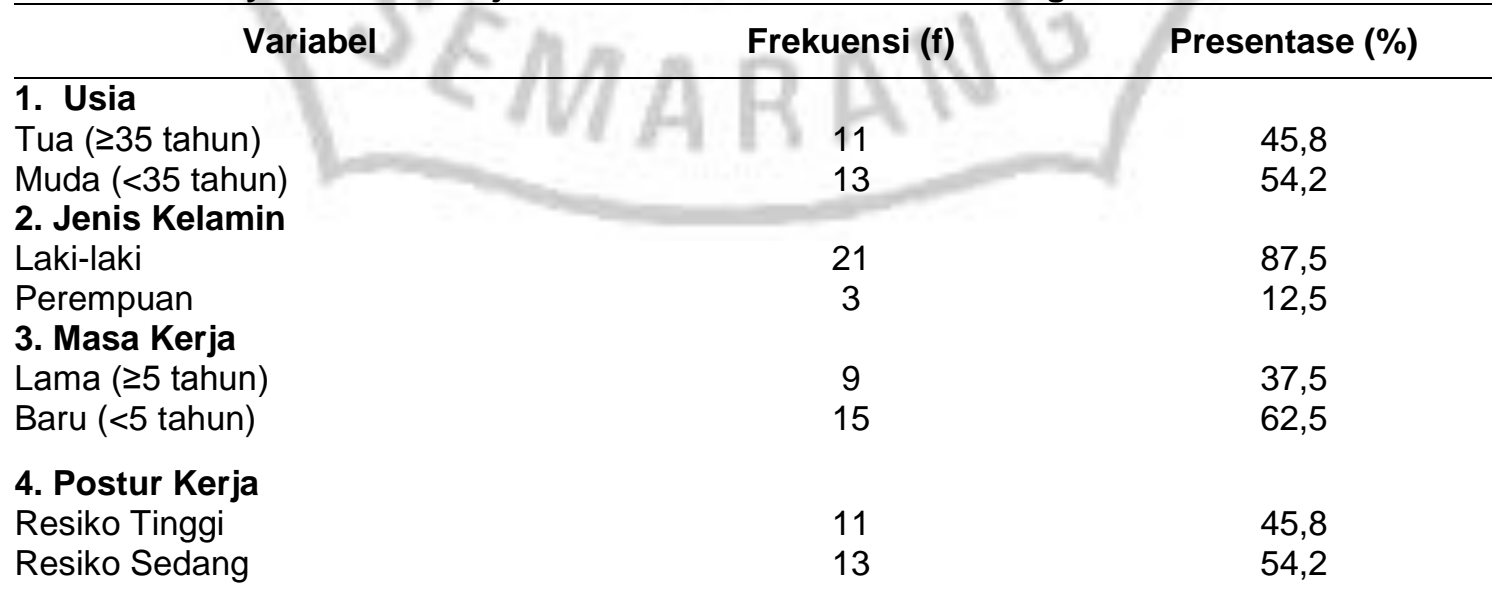




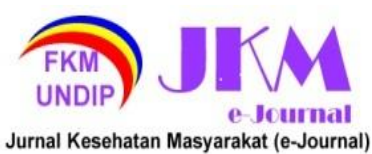

5. Durasi Kerja

Tidak Standar (>8 jam)

Standar ( $\leq 8$ jam)

6. Keluhan Nyeri Otot

Ada Keluhan (Jika score $>28$ )

Tidak Ada Keluhan (Jika score $\leq 28$ )

Berdasarkan Tabel 1 menunjukkan bahwa pekerja dengan kategori usia muda lebih banyak dibandingkan dengan kategori usia tua, yaitu sebanyak $54,2 \%$, pekerja dengan jenis kelamin laki-laki lebih banyak dibandingkan dengan jenis kelamin perempuan yaitu sebanyak $87,5 \%$, pekerja dengan kategori masa kerja baru lebih banyak dibandingkan dengan masa kerja lama yaitu sebanyak $62,5 \%$, pekerja
JURNAL KESEHATAN MASYARAKAT (e-Journal)

Volume 9, Nomor 6, November 2021

ISSN: 2715-5617 / e-ISSN: 2356-3346

http://ejournal3.undip.ac.id/index.php/jkm

Tabel 2. Rekapitulasi Titik Keluhan Nyeri Otot Pekerja Pabrik Tahu X di Kota Semarang 2021

\begin{tabular}{lcc}
\hline \multicolumn{1}{c}{ Titik Keluhan Nyeri Otot } & Frekuensi (f) & Presentase (\%) \\
\hline Leher bagian atas & 8 & 57,1 \\
Leher bagian bawah & 14 & 100 \\
Bahu kiri & 13 & 92,8 \\
Bahu kanan & 14 & 100 \\
Lengan atas kiri & 13 & 92,8 \\
Punggung & 13 & 92,8 \\
Lengan atas kanan & 14 & 100 \\
Pinggang & 14 & 100 \\
Bokong & 1 & 7.1 \\
Pantat & 0 & 0 \\
Siku kiri & 11 & 78,5 \\
Siku kanan & 11 & 78,5 \\
Lengan bawah kiri & 13 & 92,8 \\
Lengan bawah kanan & 14 & 100 \\
Pergelangan tangan kiri & 11 & 78,5 \\
Pergelangan tangan kanan & 13 & 92,8 \\
Tangan kiri & 11 & 78,5 \\
Tangan kanan & 12 & 85,7 \\
Paha kiri & 7 & 50 \\
Paha kanan & 8 & 57,1
\end{tabular}




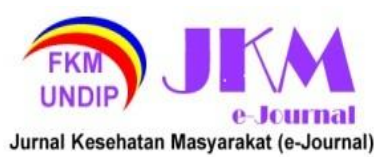

Lutut kiri

Lutut kanan

Betis kiri

Betis kanan

Pergelangan kaki kiri

Pergelangan kaki kanan

Kaki kiri

Kaki kanan
JURNAL KESEHATAN MASYARAKAT (e-Journal)

Volume 9, Nomor 6, November 2021

ISSN: 2715-5617 / e-ISSN: 2356-3346

http://ejournal3.undip.ac.id/index.php/jkm
14

14

14

14

4

4

4

4
100

100

100

100

28,5

28,5

28,5

28,5

\section{Analisis Bivariat}

a. Hubungan Postur Kerja Dengan Keluhan Nyeri Otot

Tabel 3. Hubungan Postur Kerja Dengan Keluhan Nyeri Otot

\begin{tabular}{lccccccc}
\hline & & \multicolumn{3}{c}{ Keluhan Nyeri Otot } & Jumlah & p-value \\
\cline { 3 - 7 } Postur Kerja & \multicolumn{2}{c}{ Ada Keluhan } & Tidak Ada Keluhan & & \\
\cline { 2 - 7 } & $\mathrm{f}$ & $\%$ & $\mathrm{f}$ & $\%$ & $\mathrm{f}$ & $\%$ \\
\hline Resiko Tinggi & 9 & 81,8 & 2 & 18,2 & 11 & 100 & 0.040 \\
Resiko Sedang & 5 & 38,5 & 8 & 61,5 & 13 & 100 & \\
\hline Jumlah & 14 & 58,3 & 10 & 41,7 & 24 & 100 & \\
\hline
\end{tabular}

Berdasarkan Tabel 3

menunjukkan bahwa $p$-value untuk variabel postur kerja yang diperoleh dalam penelitian ini adalah 0.040 ( $p$ value < 0.05). Pada hasil analisis statistik menunjukkan bahwa responden dengan postur kerja kategori resiko tinggi yang merasakan keluhan nyeri otot sebanyak 9 orang $(81,8 \%)$, sedangkan responden dengan postur kerja kategori sedang yang merasakan keluhan nyeri otot sebanyak 5 orang (38,5\%). Kemudian, pekerja dengan postur kerja kategori resiko tinggi yang tidak merasakan keluhan nyeri otot sebanyak 2 orang $(18,2 \%)$, sedangakn pekerja dengan postur kerja kategori resiko sedang yang tidak merasakan keluhan nyeri otot sebanyak 8 orang $(61,5 \%)$. Dari hasil penelitian ini dapat disimpulkan bahwa ada hubungan antara postur kerja dengan keluhan nyeri otot pada pekerja pabrik tahu $X$ dan pekerja dengan postur kerja kategori resiko tinggi lebih rentan mengalami keluhan nyeri otot.

Dari 14 pekerja yang mengalami keluhan nyeri otot, pekerja dengan postur kerja kategori resiko tinggi terbanyak yang memerlukan investigasi dan perbaikan segera adalah pada bagian penanganan dan penggilingan bubur kedelai sebanyak 3 orang, pemasakan / pembuatan, penyaringan tahu sebanyak 1 orang, pencetakan, pembalikan dan pengepressan tahu sebanyak 3 orang, penguapan sebanyak 1 orang dan pengiriman sebanyak 1 orang.

Umumnya, keluhan nyeri otot muncul dari kebiasaan yang dilakukan seseorang saat bekerja dan keluhan ini dapat timbul akibat postur kerja yang tidak sesuai dan dilakukan dalam durasi kerja dengan jangka waktu lama.6 Postur kerja tidak alamiah adalah postur atau sikap tubuh saat bekerja yang menyebabkan bagianbagian tubuh menjauhi posisi alamiahnya, contohnya seperti posisi leher yang terlalu mendongak atau menunduk, pergerakan lengan yang terlalu terangkat, posisi punggung yang terlalu membungkuk serta posisi lain yang tidak ergonomis. ${ }^{7}$ Postur kerja tidak alamiah dapat disebut dengan postur statis. ${ }^{8}$ Postur statis ialah postur 


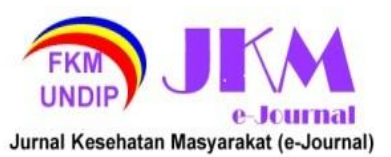

saat kerja fisik dalam posisi yang sama dimana pergerakan yang terjadi sangat minim atau gerakan yang dipertahankan $>10$ detik. Postur kerja statis yang dilakukan dalam jangka waktu yang cukup lama dapat meningkatkan risiko munculnya keluhan nyeri otot pada beberapa bagian tubuh dan dapat menurunkan kemampuan fungsional otot. Otot akan lebih mudah lelah saat bekerja dalam postur statis dibandingkan dengan saat bekerja dengan postur dinamis. ${ }^{9,10}$ Saat tubuh berada dalam posisi statis, terjadi penyumbatan aliran darah dan menyebabkan bagian tersebut kekurangan oksigen dan glukosa dari darah. Tubuh akan mengalami proses oksidasi anaerob yang menghasilkan sisa metabolisme berupa asam laktat yang tidak diangkut sehingga menumpuk dan menimbulkan nyeri pada otot. ${ }^{11}$

Pekerja pabrik tahu $\mathrm{X}$ seringkali mengalami nyeri otot baik pada saat bekerja maupun setelah bekerja, hal ini diakibatkan oleh postur kerja yang tidak sesuai dan durasi kerja yang cukup lama. Titik nyeri otot yang dialami pekerja paling banyak dialami pada bagian leher bawah, bahu, lengan atas, lengan bawah, pinggang, punggung dan betis. Postur kerja yang dilakukan oleh pekerja pabrik tahu $\mathrm{X}$ yaitu dengan posisi berdiri, duduk dan duduk berdiri, namun posisi kerja yang paling banyak digunakan adalah dengan posisi berdiri sesuai dengan bagian pekerjaan seperti pada bagian penggilingan kedelai, pemasakan bubur kedelai, penyaringan bubur kedelai, pencetakan, pemotongan, penggorengan tahu dan penguapan. Sebagian besar pekerja di pabrik tahu $X$ bekerja dengan postur kerja yang tidak sesuai seperti terlalu membungkuk, tangan terlalu terangkat, leher terlalu mendongak ke atas dan memutar pinggang dengan frekuensi yang cukup sering, hal ini terjadi dikarenakan desain kerja yang kurang mendukung atau tidak ergonomis, sehingga pekerja melakukan aktivitas kerja yang membuat postur tubuh menjauhi posisi alamiahnya. Saat melakukan pekerjaan terdapat beberapa pekerja yang memakai alat bantu kain yang diikat di pinggang sebagai penyangga tulang belakang saat mengangkat atau memindahkan bahan atau material. Pada pabrik tahu $X$ belum terdapat obat-obatan, program atau kegiatan yang dilakukan untuk mengurangi keluhan nyeri otot yang dialami pekerja, padahal nyeri otot dapat mengakibatkan kekakuan pada otot jika tidak dilakukan penanganan sesegera mungkin. Untuk itu sangat diperlukan upaya promotif, preventif, kuratif dan rehabilitatif dalam suatu pekerjaan untuk mengurangi kejadian keluhan nyeri otot.

Postur kerja normal yang sebaiknya diterapkan pekerja adalah :

1. Pada tangan dan pergelangan tangan : berada dalam keadaan garis lurus dengan jari tengah, tidak miring ataupun mengalami fleksi atau ekstensi.

2. Pada leher : berada dalam keadaan lurus dan tidak miring/memutar ke samping kiri atau kanan. Posisi miring pada leher tidak melebihi $20^{\circ}$ sehingga tidak terjadi penekanan pada discus tulang cervical.

3. Pada bahu : tidak dalam keadaan mengangkat dan siku berada dekat dengan tubuh sehingga bahu kiri dan kanan dalam keadaan lurus dan proporsional.

4. Pada punggung : tulang belakang bagian toraks dan lumbal tidak miring ke kiri atau kanan. Postur tubuh membungkuk tidak boleh lebih dari $20^{\circ} .{ }^{12}$

Hasil penelitian ini sejalan dengan penelitian sebelumnya mengenai keluhan musculoskeletal disorders (MSDs) atau nyeri otot pada pekerja manual handing, yang menemukan bahwa terdapat hubungan antara postur kerja dengan keluhan MSDs atau nyeri otot, hasil ini dibuktikan dengan dilakukannya uji korelasi spearman antara postur kerja dengan keluhan MSDs di PT Ispat Indo Sidoarjo, didapatkan nilai koefisien korelasi (r) spearman sebesar 0,770. Hasil ini diperoleh karena setiap pekerja manual handling di PT Ispat Indo memiliki faktor risiko yang dapat menyebabkan nyeri otot. Faktor penyebab keluhan nyeri otot adalah postur tubuh statis dan tidak sesuai serta adanya gerakan berulang yang 


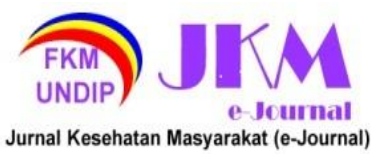

banyak ditemukan di area BRF dan Mill Equipment yang mana hal tersebut serupa dengan pabrik tahu $\mathrm{X}$ di Kota Semarang. ${ }^{13}$

Hasil penelitian ini pun sejalan dengan penelitian sebelumnya mengenai keluhan MSDs atau nyeri otot pada pekerja pembuatan paving dan batako, yang menyebutkan bahwa postur kerja yang salah merupakan faktor yang menyebabkan keluhan MSDs atau nyeri otot. Hasil keluhan yang dirasakan adalah pegal pada leher, nyeri pada punggung, pegal pada bahu, pegal pada tangan, nyeri pada lutut, kesemutan pada kaki, dimana keluhan tersebut terjadi akibat posisi leher menekuk, jongkok, badan membungkuk, mengangkat dan kegiatan memukul yang dilakukan secara berulang dan cara kerja
JURNAL KESEHATAN MASYARAKAT (e-Journal)

Volume 9, Nomor 6, November 2021

ISSN: 2715-5617 / e-ISSN: 2356-3346

http://ejournal3.undip.ac.id/index.php/jkm

b. Hubungan Durasi Kerja Dengan Keluhan Nyeri Otot

Tabel 3. Hubungan Durasi Kerja Dengan Keluhan Nyeri Otot

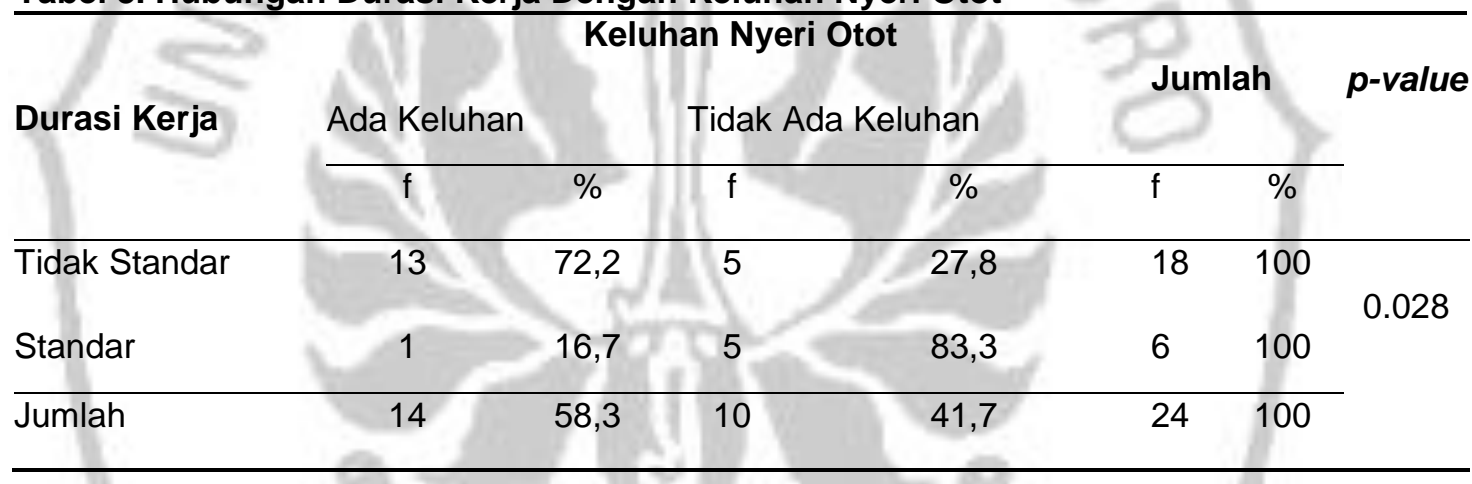

cerupa dengan cara kerja pada pabrik tahu $X$ di Kota Semarang. ${ }^{14}$

Hasil penelitian ini juga sejalan dengan penelitian sebelumnya mengenai keluhan MSDs atau nyeri otot pada pekerja pembuatan beton, yang menyatakan bahwa postur kerja berhubungan dengan adanya keluhan MSDs. Penyebab munculnya keluhan MSDs atau nyeri otot adalah adanya pembebanan pada otot secara berulang dengan postur kerja yang tidak sesuai sehingga menyebabkan cidera pada jaringan lunak dan sistem saraf saat melakukan aktivitas pekerjaan. Cidera ini diekspresikan sebagai pegal, nyeri, sakit atau kesemutan, pembengkakan serta kelemahan otot. ${ }^{15}$

Berdasarkan Tabel 3 menunjukkan bahwa $p$-value untuk variabel durasi kerja yang diperoleh dalam penelitian ini adalah sebesar 0.028 ( $p$-value < 0.05). Pada hasil analisis statistik menunjukkan bahwa responden dengan durasi kerja kategori tidak standar yang merasakan keluhan nyeri otot sebanyak 13 orang $(72,2 \%)$, sedangkan responden dengan durasi kerja kategori standar yang merasakan keluhan nyeri otot sebanyak 1 orang (16,7\%). Kemudian, pekerja dengan durasi kerja tidak standar yang tidak merasakan keluhan nyeri otot sebanyak 5 orang $(27,8 \%)$, sedangkan pekerja dengan durasi kerja standar yang tidak merasakan keluhan nyeri otot sebanyak 5 orang $(83,3 \%)$. Dari hasil penelitian ini dapat disimpulkan bahwa ada hubungan antara durasi kerja dengan keluhan nyeri otot pada pekerja Pabrik Tahu $\mathrm{X}$ di Kota Semarang dan pekerja dengan durasi kerja tidak standar lebih rentan mengalami keluhan nyeri otot.

Durasi kerja merupakan lamanya pajanan dari faktor risiko selama bekerja. Waktu yang dilakukan untuk mempertahankan postur kerja juga dapat disebut sebagai lamanya waktu/durasi paparan terhadap faktor risiko. Semakin lama durasi paparan maka risiko cidera yang akan terjadi pada seseorang akan semakin meningkat. Bila pekerjaan berlangsung dalam jangka waktu cukup lama, maka kemampuan tubuh akan menurun dan dapat menyebabkan keluhan pada tubuh. ${ }^{7,9}$ Maka dari itu, semakin lama seseorang mempertahankan postur tubuhnya saat bekerja maka akan semakin besar pula risiko munculnya keluhan nyeri otot yang dirasakan. 


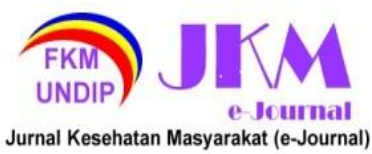

Berdasarkan peraturan yang ada pada Undang-undang RI No.13 Tahun 2003 Tentang Ketenagakerjaan Pasal 77 yang menyatakan bahwa setiap pengusaha wajib melaksanakan ketentuan waktu kerja yaitu 7 jam per hari dan 40 jam per minggu untuk jangka waktu 6 hari kerja dalam 1 minggu, atau 8 jam per hari dan 40 jam per minggu untuk 5 hari kerja dalam 1 minggu. Durasi kerja yang baik yaitu 6 hingga 8 jam per hari dan sisanya digunakan untuk istirahat. Ketentuan durasi kerja pabrik tahu $X$ yaitu \pm 8 jam dalam sehari, namun durasi kerja yang dihabiskan pekerja tidak selalu sesuai dengan ketentuan pabrik tersebut, hal ini dikarenakan adanya permintaan komsumen yang cukup banyak dan hanya terdapat satu shift kerja yang mengharuskan pekerja menyelesaikan pekerjaannya walau sudah melebihi jam kerja yang telah ditentukan pabrik. Memperpanjang durasi kerja lebih dari biasanya dapat menyebabkan penurunan efisiensi kerja selain itu dapat menjadi pemicu terjadinya kelelahan kerja, penyakit akibat kerja dan bahkan kecelakaan kerja. Secara fisiologis, istirahat kerja sangat dibutuhkan untuk mempertahankan produktivitas dan kapasitas kerja. ${ }^{16}$ Jika durasi kerja melebihi waktu kerja yang telah ditentukan maka akan rentan terkena risiko keluhan otot skeletal karena tingkat keluhan yang dirasakan juga akan semakin lama. ${ }^{17}$

Hasil penelitian ini sejalan dengan penelitian sebelumnya mengenai keluhan nyeri otot pada nelayan, yang menemukan bahwa durasi kerja memiliki hubungan yang signifikan dengan keluhan nyeri otot. Keluhan nyeri otot dapat terjadi karena adanya konstraksi otot yang berlebihan akibat dari pemberian beban kerja yang terlalu berat dengan durasi pembebanan yang panjang. Hal ini terjadi dikarenakan apabila bekerja dalam jangka waktu yang lama maka dapat menimbulkan beban tambahan pada otot yang pada akhirnya menyebabkan nyeri otot, padahal standar durasi kerja yang ditetapkan undang-undang selama 8 jam/hari dimaksudkan untuk menjaga kesehatan para pekerja. ${ }^{18}$
Hasil penelitian ini pun sejalan
dengan penelitian sebelumnya
mengenai MSDs pada petani, yang
menyatakan bahwa keluhan MSDs atau nyeri otot berkaitan dengan durasi kerja, hal ini diperkuat dengan di temukannya beberapa keluhan nyeri otot pada beberapa anggota tubuh petani setelah bekerja dan durasi kerja yang dilakukan petani dimulai dari pukul 06.30-16.00 yang mana dapat dikatakan tidak optimal, seharusnya durasi kerja yang baik bagi pekerja yaitu $\leq 8$ jam dalam sehari. Apabila jam kerja melebihi ketentuan yang telah ditetapkan, akan ditemukan hal-hal seperti penurunan kecepatan kerja, gangguan kesehatan yang dapat mengakibatkan rendahnya tingkat produktivitas kerja. Hal tersebut dapat beresiko menimbulkan nyeri otot yang akan menyebabkan MSDs. ${ }^{19,20}$ Durasi kerja yang dilakukan pada penelitian tersebut sejalan dengan penelitian ini dikarenakan durasi kerja yang serupa dengan durasi kerja pada pabrik tahu $\mathrm{X}$ yaitu sebagian besar termasuk kategori tidak standar (>8 jam).

Penelitian ini juga sejalan dengan penelitian sebelumnya mengenai keluhan otot sendi pada pekerja komputer, yang menyatakan bahwa ada hubungan signifikan antara durasi kerja dengan keluhan otot sendi. Hal ini dikarenakan keluhan otot sendi dapat terjadi apabila durasi kerja yang melebihi waktu kerja yang telah diperkenankan maka akan lebih mudah terkena risiko keluhan otot skeletal sebab tingkat keluhan yang dirasakan juga akan semakin lama. ${ }^{21}$

\section{KESIMPULAN}

Berdasarkan penelitian yang telah dilakukan, dapat disimpulkan bahwa ada hubungan antara postur kerja $(p$-value $=0.040)$ dan durasi kerja ( $p$-value $=0.028$ ) dengan keluhan nyeri otot pada pekerja pabrik tahu $\mathrm{X}$ di Kota Semarang.

\section{SARAN}

Saran yang diberikan oleh peneliti yaitu Melakukan peregangan otot tubuh selama kurang lebih 10 detik sampai dengan 3 menit sekali pada jeda waktu kerja. Pada proses kerja mengangkat dan memindahkan bahan atau material dilakukan oleh 2 orang. Memperbaiki postur kerja dengan menerapkan postur kerja 


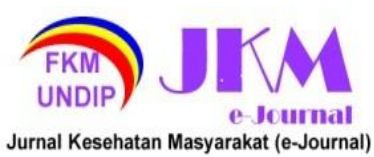

yang sesuai dengan prinsip ergonomi pada seluruh bagian proses produksi. Mengubah desain kerja dengan menyediakan meja yang sejajar dan ergonomis di bagian penanganan, penggilingan dan pemotongan tahu. Menerapkan sistem istirahat kerja teratur bagi seluruh pekerja selama \pm 1 jam yaitu pada pukul $12.00-13.00$. Menyediakan krim otot atau balsam yang mengandung bahan methyl salicylate untuk mengurangi keluhan nyeri otot.

\section{DAFTAR PUSTAKA}

1. Irjayanti A, Nurjazuli, Suwondo A. Hubungan Kadar Debu Terhirup (Respirable) dengan Kapasitas Vital Paksa Paru pada Pekerja Mebel Kayu di Kota Jayapura. 2012.

2. Asmarani FL, Dewi LGRS. Bekam Menurunkan Keluhan Myalgia. Keperawatan Respati Yogyakarta. September 2019.

3. Sumardiyono S, Lowa NW, Azzam AM, Huda KN, Nurfauziah N. Kejadian Myalgia pada Lansia Pasien Rawat Jalan. JRST J Ris Sains dan Teknologi. Desember 2017.

4. Tomaszewski M, Stepien ,KM, Tomaszewska J.Statin-induced myopathies. 2011.

5. Affa MN, Putra BI. Analisis Manual Material Handling Pada Pekerja Borongan Di PT. JC dengan Metode NBM dan RWL. PROZIMA Product Optim Manuf Syst Eng. April 2017.

6. I Alfara, Iftadi, R.D. Astuti. Analisis Postur Kerja Operator Perakitan Di Yessy Shoes Untuk Mengidentifikasi Resiko Gangguan Muskuloskeletal Akibat Kerja. 2017.

7. Safitri, A,G, B, Widjasena, B, Kurniawan. Analisis Penyebab Keluhan Pekerja DI Pabrik Sepatu Dan Sandal Kulit Kurnia Di Kota Semarang. 2017.

8. Wijayati EW. Risiko Postur Kerja Terhadap Keluhan Subyektif Nyeri Leher Pada Pekerja Industri Kerajinan Kulit. 2020.

9. Tarwaka. Ergonomi Industri Dasar-dasar Pengetahuan Ergonomi dan Aplikasi di Tempat Kerja. 2015.

10. Melia, D.S, Imania, D,R, Fis, M. Perbedaan Pengaruh Pemberian Static Stretching Exercise Dan Muscle Energy Technique Terhadap Peningkatan Aktifitas Fungsional Leher Pada Kondisi Neck Pain. 2018.

11. Ulfah, Nur, Harwanti, S, Nurcahyo, P. J. Sikap Kerja dan Risiko Musculoskeletal Disorders Pada Pekerja Loundry. Jurnal Kesehatan Masyarakat Nasional. 2014.

12. Septianto, Andry. Postur Kerja. Manajemen dan Teknik Indutri. Agustus 2017.

13. Evadarianto N. Postur Kerja Dengan
Keluhan Musculoskeletal Disorders Pada Pekerja Manual Handling Bagian Rolling Mill. Indonesian J Occuppational Safety Health. November 2017.

14. Mahardika T. Perancangan Fasilitas Kerja untuk mengurangi Keluhan Musculoskeletal Disorders (MSDs) dengan Metode Rapid Entire Body Assessment pada Pekerja Pembuatan Paving dan Batako pada UKM Usaha Baru. 2017.

15. Rahman A. Analisis Postur Kerja Dan Faktor Yang Berhubungan Dengan Keluhan Musculoskeletal Disorders (MSDS) Pada Pekerja Beton Sektor Informal Di

16. Kelurahan Samata Kecamatan Somba Opu Kabupaten Gowa. 2017.

17. Azis A.H. Faktor Yang Berhubungan Dengan Keluhan Nyeri Otot Skeletal (MSDs) Pada Pekerja Bongkar Muat Di Pelabuhan Soekarno Hatta Makassar. 2018.

18. Suma'mur, PK. Higiene Perusahaan Kesehatan Kerja. Jakarta. 2009.

19. Atthariq A, Putri ME. Faktor - Faktor yang Berhubungan dengan Kejadian Myalgia pada Nelayan di Desa Batukaras Pangandaran Jawa Barat. J Kedokteran Dan Kesehatan. Maret 2018.

20. Istighfaniar K, Mulyono M. Evaluasi Postur Kerja Dan Keluhan Muskoloskeletal Pada Pekerja Instalasi Farmasi. Indonesian J Occuppational Safety and Health. 2017.

21. Ucik Utami, Siti Rabbani Karimuna, Nurnashriana Jufri. Hubungan Lama Kerja, Sikap Kerja Dan Beban Kerja Dengan Muskuloskeletal Disorders (MSDS) Pada Petani Padi Di Desa Ahuhu Kecamatan Meluhu Kabupaten Konawe Tahun 2017. 2017.

22. A.M. HTS, M. Furqaan Naiem, Lalu Muh. Saleh. Faktor Yang Berhubungan Dengan Keluhan Otot Sendi Pada Operator Komputer Bagian Keuangan Universitas Hasanuddin Makassar. FKM Unhas. 2012. 